\title{
Influence of Meteorological Parameters on the Incidence and Abundance of Leaf Miner (Aproaerema modicella), Aphid (Aphis craccivora), and Bihar Hairy Caterpillar (Spilosoma obliqua) of Groundnut (Arachis hypogaea L.)
}

\author{
Virendra Kumar* and Swarnali Bhattacharya
}

Agricultural Entomology, Department of Plant Protection, Palli Siksha Bhavana, VisvaBharati University, Sriniketan, West Bengal, India

*Corresponding author

\section{A B S T R A C T}

Keywords

Aproaerema

modicella, Aphis

craccivora,

Spilosoma obliqua

and Groundnut

(Arachis hypogaea

L.)

Article Info

Accepted:

12 November 2019

Available Online:

10 December 2019
The population of Aproaerema modicella initiated from $11^{\text {th }}$ standard week when the population was maximum 5.82/plant. The minimum leaf miner population of 0.40 /plant was recorded at $15^{\text {th }}$ standard week when minimum temperature, relative humidity and sunshine hours were recorded highest. The lowest population of Aphis craccivora was recorded as 1.92 / plants in the $14^{\text {th }}$ standard week while population of BHC was recorded as 0.35 larvae/plants and $13^{\text {th }}$ standard week. The population of Aphis craccivora and Spilosoma obliqua was found maximum (20.10/ plants) and (7.23 larvae/plant) during $17^{\text {th }}$ standard week when maximum temperature, minimum temperature, temperature gradient, relative humidity, and sunshine hour was $\left(42.32^{\circ} \mathrm{C}, 23.89^{\circ} \mathrm{C}, 19.91^{\circ} \mathrm{C}, 64.42 \%, 8.51 \mathrm{hr}\right)$ respectively. The larval and aphid population was found to decrease steadily after the $17^{\text {th }}$ standard week due to increase in the age of the crop and rainfall.

\section{Introduction}

Groundnut (Arachis hypogaea L.) belongs to family Fabaceae, is an important oil seed crop that contributes a major role in economy around the world (FAO, 2006; Narada et al., 2003; Nwokolo, 1996; Wiess, 2000). It is the 3rd most important source of vegetable protein and contains 50 percent edible oil, 28 percent digestible protein and 20 percent carbohydrates (Bhatti and Soomro, 1996; Christensen et al., 2004; Shah et al., 2012). In India, Groundnut is cultivated during kharif season (June-July to September-October) mostly under rainfed conditions with a few protective irrigations. The crop is also grown during Rabi season (October-November to February-March) under residual moisture and 
minimal irrigation situation. In summer (January - February to April-May), groundnut is grown as an irrigated crop. The spring groundnut is grown from March-April to JulyAugust. The crop can be grown successfully in places receiving a rainfall of 500 to $1250 \mathrm{~mm}$ and performs better in the sandy loam and loamy soils and also in black soils with good drainage. Several factors are responsible for economic losses to groundnut crop such as variable rainfall, low soil fertility, crop management practices, pests and diseases (Naab et al., 2004). Several insect pests attack the groundnut crop that may cause moderate to severe damage (Javed et al., 2014). Among groundnut producing countries of Asia (including Pakistan) the major insect pest of groundnut include leaf miner, white grub, jassid, aphid, thrips, red hairy caterpillars and termites (Salihah et al., 1988; Sheirdil et al., 2012). Soil insect pests cause serious economic losses to groundnut crop (Wightman et al., 1990). The incidences of different insect pest of groundnut are examined in respect to abiotic factors. Therefore, an investigation was conducted to study the Incidence and abundance of leaf miner (Aproaerema modicella), Aphid (Aphis craccivora), and Bihar hairy caterpillar (Spilosoma obliqua) in relation to meteorological parameters of West Bengal.

\section{Materials and Methods}

The field experiment was conducted during pre-summer season of 2015-2016 in plot number East-4 at the Agriculture college farm, Palli Siksha Bhavana (Institute of Agriculture) Visva-Bharati, Sriniketan, Birbhum, which is situated between $23.39^{\circ} \mathrm{N}$ latitude and $87.42^{\circ}$ E longitudes having an altitude of $58.90 \mathrm{~m}$ above the mean sea level in the sub-humid lateritic belt of West Bengal. The physiographic characteristic is undulated with mid to steep gradient, and terraces of distinct top sequence. In high lands the soil consists of gravels and poor inorganic matter. The physico-chemical properties of the soil of experimental site are presented in Table 1.

It is evident from the above information that the soil of the experimental plots was sandy loam, with high percent of clay. The soil was acidic, low in total nitrogen and available phosphate and moderate in potash contents.

The details of climatic factors (temperature, rainfall, relative humidity, sunshine hours) during the period of experimentation as observed and recorded from the meteorological observatory, Sriniketan is presented in (Table 2). Variety TAG-24 was chosen for the present research work which is grown well in dry season.

Data on the observations of insect-pest incidence of leaf miner, aphid and bihar hairy caterpillar was taken from 10 tagged plants per replication from each standard week. The collection of data on insect-pest incidence continued till the $22^{\text {nd }}$ week. The groundnut plants were closely examined at regular intervals commencing from flowering to pod maturity. The data on insect-pests (leaf miner, aphids, and bihar hairy caterpillar) was recorded at each standard week starting from early vegetative to pod maturity.

\section{Results and Discussion}

\section{Leaf miner}

The population of leaf miner (Aproaerema modicella) initiated from $2^{\text {nd }}$ week of March i.e. from $11^{\text {th }}$ standard week when the population was maximum 5.82/ plant. The population of leaf miner gradually decreased as the crop entered into the flowering stage. The population of leaf miner was nil from the $16^{\text {th }}$ standard week. The minimum leaf miner population of $0.40 /$ plant was recorded at $15^{\text {th }}$ standard week i.e. the second week of April 
when minimum temperature, relative humidity and sunshine hours were recorded highest (Table 2). The present findings are in accordance with Hanamant Gadad et al., (2013) who recorded that the incidence of leaf miner was noticed during 5 to 14 th $\mathrm{MSW}\left(1^{\text {st }}\right.$ week of Feb to $1^{\text {st }}$ week of April) at Kurvinkoppa with a population range of 0.46 to 4.20 larvae per plant. While during $14^{\text {th }}$ MSW (1st week of April) lowest leaf miner incidence was recorded (0.46 larvae/plant). Chaudhuri and Senapathi (2004) observed that seasonal incidence of leaf miner was much lower at beginning of the season. The higher level of infestation was maintained during $11^{\text {th }}-19^{\text {th }}$ standard week.

\section{Aphid}

Aphis craccivora is another important insectpest in this region and its population was found throughout the crop growth stage. The aphid population per $10 \mathrm{~cm}$ shoot (mainly till 3 leaves) of groundnut was recorded as 1.92 / plants in the $14^{\text {th }}$ standard week. The results substantiate its attack in the initial vegetative stage when maximum temperature, minimum temperature, temperature gradient, relative humidity, and sunshine hour was $\left(36.45^{\circ} \mathrm{C}\right.$, $24.12^{0} \mathrm{C}, \quad 12.33^{\circ} \mathrm{C}, \quad 67.85 \%$ and $5.89 \mathrm{hr}$ ) respectively. The leaf damage percentage gradually increased from $14^{\text {th }}$ standard week with a maximum (20.10/ plants) (Table 2) during $17^{\text {th }}$ standard week when bright sunshine hour and relative humidity recorded $7.98 \mathrm{hr}$ and 67.29 respectively. Gradually the population of aphid declined due to increase in the age of the crop and rainfall. The present findings are in agreement with Singh et al., (2005). They revealed that maximum population of aphid was observed at $38^{\text {th }}$ standard week, thereafter the population declined and reached to minimum levels during $43^{\text {rd }}$ standard week. The aphid appeared during $32^{\text {nd }}$ standard meteorological week (SMW) i.e. $6^{\text {th }}-12^{\text {th }}$ August ( $2^{\text {nd }}$ week) with a mean population of $2.20 \mathrm{aphid} / 3$ leaves. The population increased gradually and attained its peak in the third week of September $\left(38^{\text {th }}\right.$ SMW) with a mean population of 7.60 aphid/3 leaves, when the mean atmosphere temperature and relative humidity were $26.15^{\circ} \mathrm{C}$ and $68.05 \%$, respectively. Thereafter, the population declined and reached to minimum levels of 1.00 aphid/3 leaves during $43^{\text {rd }}$ SMW i.e. $22^{\text {nd }}$ $28^{\text {th }}$ October. The temperature and relative humidity favored the pest population build up.

Similar reports have been observed by Karim et al., 2001, who reported that the aphid population started growing from August, reached highest in January and almost vanished in April.

\section{Bihar Hairy Caterpillar}

Spilosoma obliqua is one of the major insectpests of Groundnut. It feeds on the leaves voraciously and defoliates the plants. This pest is polyphagous in nature and was observed in groundnut from vegetative stage to pod maturity stage.

Table.1 The physico-chemical properties of the soil of experimental site

\begin{tabular}{|c|c|c|c|c|c|c|c|}
\hline $\begin{array}{c}\text { Sand } \\
(\boldsymbol{\%})\end{array}$ & $\begin{array}{c}\text { Silt } \\
(\boldsymbol{\%})\end{array}$ & $\begin{array}{c}\text { Clay } \\
(\boldsymbol{\%})\end{array}$ & $\mathbf{p H}$ & $\begin{array}{c}\text { Organic } \\
\text { carbon }(\boldsymbol{\%})\end{array}$ & $\begin{array}{c}\text { Available N } \\
(\mathbf{K g} / \mathbf{H a})\end{array}$ & $\begin{array}{c}\text { Available P } \\
(\mathbf{K g} / \mathbf{H a})\end{array}$ & $\begin{array}{c}\text { Available K } \\
(\mathbf{K g} / \mathbf{H a})\end{array}$ \\
\hline $\mathbf{7 5 . 6}$ & 14.8 & 9.6 & 5.65 & 0.33 & 197.35 & 17.43 & 141.50 \\
\hline
\end{tabular}


Table.2 Influence of meteorological parameters on the incidence and abundance of different insect pest of groundnut (Arachis hypogaea L.) during 2016

\begin{tabular}{|c|c|c|c|c|c|c|c|c|c|c|}
\hline \multirow[t]{2}{*}{ SW } & \multirow{2}{*}{$\begin{array}{l}\text { Leaf miner } \\
\text { population } \\
\text { / plant }\end{array}$} & \multirow{2}{*}{$\begin{array}{c}\text { Aphid } \\
\text { Population/ } \\
10 \mathrm{~cm} \\
\text { Plants }\end{array}$} & \multirow[b]{2}{*}{$\begin{array}{c}\text { Bihar } \\
\text { Hairy } \\
\text { caterpill } \\
\text { ar } \\
\text { Larvae/ } \\
\text { plant }\end{array}$} & \multicolumn{7}{|c|}{ Important Weather Parameters As Recorded During The Respective Standard Week } \\
\hline & & & & $\begin{array}{c}\text { Correlated } \\
\text { With The } \\
\text { Standard } \\
\text { Week }\end{array}$ & $\begin{array}{c}\text { Max }^{\mathbf{m}} \\
\text { Temp. }\left({ }^{\circ} \mathrm{C}\right)\end{array}$ & $\begin{array}{c}\operatorname{Min}^{\mathbf{m}} \\
\text { Temp. }\left({ }^{\circ} \mathrm{C}\right)\end{array}$ & $\begin{array}{l}\text { Temp. } \\
\text { Gradient } \\
\left({ }^{\circ} \mathrm{C}\right)\end{array}$ & $\begin{array}{l}\text { RH } \\
(\%)\end{array}$ & $\begin{array}{c}\text { Rainfall } \\
\text { (mm) }\end{array}$ & $\begin{array}{l}\text { Sunshine } \\
\text { Hour }\end{array}$ \\
\hline $11^{\text {th }}$ & 5.82 & 0.00 & 0.00 & $10^{\text {th }}$ & 33.59 & 20.19 & 13.4 & 66.85 & 0.04 & 7.04 \\
\hline $12^{\text {th }}$ & 3.06 & 0.00 & 0.00 & $11^{\text {th }}$ & 36.1 & 20.6 & 15.5 & 62.42 & 0.07 & 8.7 \\
\hline $13^{\text {th }}$ & 0.68 & 0.00 & 0.35 & $12^{\text {th }}$ & 35.92 & 23.14 & 12.78 & 51.85 & 2.15 & 4.1 \\
\hline $14^{\text {th }}$ & 0.60 & 1.92 & 1.18 & $13^{\text {th }}$ & 36.45 & 24.12 & 12.33 & 67.85 & 0.00 & 5.89 \\
\hline $15^{\text {th }}$ & 0.40 & 3.42 & 3.69 & $14^{\text {th }}$ & 41.95 & 26.42 & 17.05 & 42.42 & 0.00 & 9.64 \\
\hline $16^{\text {th }}$ & 0.00 & 7.56 & 5.43 & $15^{\text {th }}$ & 41.22 & 22.41 & 14.8 & 67.29 & 0.00 & 7.98 \\
\hline $17^{\text {th }}$ & 0.00 & 20.10 & 7.23 & $16^{\text {th }}$ & 42.32 & 23.89 & 19.91 & 64.42 & 0.00 & 8.51 \\
\hline $18^{\text {th }}$ & 0.00 & 10.62 & 5.77 & $17^{\text {th }}$ & 38.81 & 24.72 & 14.92 & 66.71 & 0.15 & 6.9 \\
\hline $19^{\text {th }}$ & 0.00 & 8.31 & 5.03 & $18^{\text {th }}$ & 38.51 & 24.72 & 13.43 & 87.14 & 3.05 & 8.99 \\
\hline $20^{\text {th }}$ & 0.00 & 3.58 & 2.59 & $19^{\text {th }}$ & 36.54 & 24.85 & 11.69 & 72.85 & 7.22 & 8.54 \\
\hline $21^{\mathrm{st}}$ & 0.00 & 1.29 & 2.57 & $20^{\text {th }}$ & 35.31 & 25.61 & 9.7 & 70.29 & 1.6 & 5.72 \\
\hline $22^{\text {nd }}$ & 0.00 & 0.00 & 1.63 & $21^{\text {st }}$ & 35.5 & 24.21 & 11.29 & 71.5 & 3.99 & 5.07 \\
\hline
\end{tabular}


The lowest larval population of 0.35 larvae/plant was observed during the $13^{\text {th }}$ standard week (Table 2) when maximum temperature, minimum temperature, temperature gradient, relative humidity, rainfall and sunshine hour was (35.92, $23.14^{0} \mathrm{C}, 12.78^{\circ} \mathrm{C}, 51.85^{\circ} \mathrm{C}, 2.15 \%, 4.1 \mathrm{hr}$ ). The highest larval population was observed during the $17^{\text {th }}$ standard week (7.23 larvae/plant) when maximum temperature, minimum temperature, temperature gradient, relative humidity, and sunshine hour was $\left(42.32^{\circ} \mathrm{C}, 23.89^{\circ} \mathrm{C}, 19.91^{\circ} \mathrm{C}, 64.42 \%, 8.51 \mathrm{hr}\right)$ respectively. The larval population was found to decrease steadily after the $17^{\text {th }}$ standard week.

Biswas (2006) Studied the incidence of hairy caterpillar, S. obliqua on sesame at Oilseed Research Centre, BARI, Gazipur and found that the pest appeared in the sesame crop in the fourth week of April at the flowering stage at 45 - 55 DAS and remained up to third week of June at pod maturity stage, 90 - 95 DAS. The peak population of $S$. obliqua $(4.00-4.50$ larvae/ plant) and its severe infestation (100\% infestation) was recorded in the fourth week of May, at pod filling stage, 60-70 DAS of the crop.

The experiment concluded that the highest infestation of leaf miner was recorded as 5.82/plant at initial period of crop growth and gradually decreased as the crop entered into the flowering stage. Highest infestation of aphid and BHC was recorded as (20.10/ plants) and (7.23 larvae/plant) during $17^{\text {th }}$ standard week when maximum temperature, minimum temperature, temperature gradient, relative humidity, and sunshine hour was $\left(42.32^{\circ} \mathrm{C}, 23.89^{\circ} \mathrm{C}, 19.91^{0} \mathrm{C}, 64.42 \%, 8.51 \mathrm{hr}\right)$ respectively.

\section{References}

Bhatti LM, Soomro AH, 1996. Agriculture inputs and field crop production in
Sindh. Agri. Res. Sindh, 56-69

Biswas, G. C. 2006. Incidence and management of hairy caterpillar (Spilarctia obliqua Walker) on sesame. J. Aric. Rural Dev., 4 (1 and 2): 95100.

Chaudhuri, N. and S. K. Senapati 2004. Incidence and biology of Leaf miner (L. trifoli Burgess) on tomato as influenced by weather conditions. Ann. Pl. Protec. Sci., 12(1): 55-58.

Christensen JH, Olesen JE, Feddersen $\mathrm{OH}$, Andersen UJ, Heckrath G, Harpoth R, Andersen LW. 2004. Application of seasonal climate forecasts for improved management of crops in western Africa. Danish Climate Centre, Report 03-02, pp. 17.

Dabhade, P.L., Bapodra, J.G., Jethava, D.M., Rathod, R.T. and Dabhi M.V. 2012. Estimation of yield losses due to major insect-pests of groundnut in Gujarat. Legume Res.-An International J., 35(4): 354-356.

FAO. 2006. FAO production yearbook, Vol. 60, Rome, Italy

Hanamant Gadad, Mahabaleshwar Hegde and R. A. Balikai 2013. Seasonal incidence of Spodoptera litura and Leaf miner in rabi/summer groundnut. J. Exp. Zool. India 16(2) : 619-622

Javed H, Javaid I, Mateen, Z. 2014. Response of Different Cultivars of Groundnut, Aarachis hypogaea L. (Fabaceae: Fabales) to Aphids, Aphis craccivora K. (Aphididae: Homoptera) in Interaction with Local Weather Factors. Pak. J. Zool., 46: 75- 81.

Karim, K.N.S., Das, B.C. and Khalequzzaman, M. 2001. Population Dynamics of Aphis gossypii Glover (Homoptera: Aphididae) at Rajshahi, Bangladesh. J. Biol. Sci. 1:492-95.

Monobrullah, Md.; Poonam Bharti, Uma Shankar, Gupta, R. K., Kuldeep Srivastava and Hafeez Ahmad 2007. 
Seasonal incidence of Spodoptera litura on cauliflower and tomato. Annal. Pl. Prot. Sci., 15 (1): 73-76.

Naab JB, Singh P, Boote KJ, Jones JW, Marfo KO. 2004. Using the CROPGROPeanut Model to Quantify Yield Gaps of Peanut in the Guinean Savanna Zone of Ghana. Agron. J. Amer., 96: 1231-1242.

Narda NK, Thaman S, Lubana PPS. 2003. Growth and yield of summer planted bunch groundnut (Arachis hypogaea L.) as influenced by irrigation methods. Indian J. Agric. Res., 73:167- 168 .

Nwokolo E. 1996. Peanut (Arachis hypogaea L.). In: Food and fee from legumes and oilseeds (eds. E. Nwokolo and J. Smartt). Chapman and Hall, New York, pp. 49-63.

Salihah Z, Shah M, Sattar A. 1988. Survey of sugarcane termites of Nowshera and Charsada tehsils. Proceeding of 8th Pakistan congress of Zoology, 8: 289297.
Shah H, Khan MA, Azeem T, Majid A, Mehmood A. 2012. The impact of gypsum application on groundnut yield in rainfed Pothwar: an economic perspective. Lahore J. Econ., 17: 83100

Sheirdil RA, Mahmood A, Khan RU, Khalid R, Amara U. 2012. Groundnut; a crop for subsistence in edible oil production in Pakistan. In: Agrihunt. Retrieved October, 30, 2013.

Singh S, Kumar A, Awasthi B.K. 2005, Study of sucking and leaf feeding insect in relation to weather parameters on the brinjal crop. Vegetable Science; 32:210-212.

Weiss EA. 2000. Oilseed Crops. London: Blackwell Science

Wightman JA, Dick KM, Ranga-Rao GV, Shanower TG, Gold CG. 1990. Pests of groundnut in the semi-arid tropics. In: Insect pests of tropical food legumes. John Wiley and Sons, Chichester, England, UK, 243-322.

\section{How to cite this article:}

Virendra Kumar and Swarnali Bhattacharya. 2019. Influence of Meteorological Parameters on the Incidence and Abundance of Leaf Miner (Aproaerema modicella), Aphid (Aphis craccivora), and Bihar Hairy Caterpillar (Spilosoma obliqua) of Groundnut (Arachis hypogaea L.). Int.J.Curr.Microbiol.App.Sci. 8(12): 1225-1230. doi: https://doi.org/10.20546/ijcmas.2019.812.151 